\title{
Iron deficiency or anemia of inflammation?
}

\section{Differential diagnosis and mechanisms of anemia of inflammation}

\author{
Manfred Nairz · Igor Theurl · Dominik Wolf · Günter Weiss
}

Received: 19 January 2016 / Accepted: 30 May 2016 / Published online: 24 August 2016

(C) The Author(s) 2016. This article is available at SpringerLink with Open Access.

\begin{abstract}
Summary Iron deficiency and immune activation are the two most frequent causes of anemia, both of which are based on disturbances of iron homeostasis. Iron deficiency anemia results from a reduction of the body's iron content due to blood loss, inadequate dietary iron intake, its malabsorption, or increased iron demand. Immune activation drives a diversion of iron fluxes from the erythropoietic bone marrow, where hemoglobinization takes place, to storage sites, particularly the mononuclear phagocytes system in liver and spleen. This results in iron-limited erythropoiesis and anemia. This review summarizes current diagnostic and pathophysiological concepts of iron deficiency anemia and anemia of inflammation, as well as combined conditions, and provides a brief outlook on novel therapeutic options.
\end{abstract}

Keywords Anemia of inflammation - Anemia of chronic disease · Iron · Hepcidin · Macrophage

\section{Eisenmangel oder Entzündungsanämie? Differenzialdiagnose und Mechanismen der Entzündungsanämie}

Zusammenfassung Eisenmangel und Immunaktivierung sind die zwei häufigsten Ursachen der Anämie. In beiden Situationen besteht ursächlich eine Störung

\footnotetext{
M. Nairz $(\bowtie) \cdot$ I. Theurl $\cdot$ G. Weiss $(\bowtie)$

Department of Internal Medicine VI, Infectious Diseases, Immunology, Rheumatology, Pneumology, Medical

University of Innsbruck, Anichstraße 35, 6020 Innsbruck, Austria

manfred.nairz@i-med.ac.at; guenter.weiss@i-med.ac.at

D. Wolf

Medical Clinic III, Department of Oncology, Hematology and Rheumatology, University Clinic Bonn (UKB), Bonn, Germany
}

der Eisenhomöostase. Die Eisenmangelanämie beruht auf einer Verminderung des Gesamtkörpereisens infolge von Blutverlust, unzureichender alimentärer $\mathrm{Zu}$ fuhr oder intestinaler Absorption bzw. erhöhtem Bedarf an Eisen. Immunaktivierung führt bei normalem Gesamtkörpereisen zu dessen Umverteilung vom erythropoetischen Knochenmark, der primären Stelle der Hämoglobinproduktion, in das mononukleäre Phagozytensystem der Leber und Milz, die Hauptorgane der Eisenspeicherung. Dies führt letztlich zur Anämie. In dem vorliegenden Übersichtsartikel werden aktuelle diagnostische und pathophysiologische Konzepte von Eisenmangelanämie, Entzündungsanämie sowie kombinierter Anämie zusammengefasst und ein kurzer Ausblick auf neue Therapieoptionen geboten.

Schlüsselwörter Entzündungsanämie · Anämie bei chronischer Erkrankung · Eisen · Hepcidin · Makrophage

\section{Introduction}

Iron deficiency (ID) can occur in two major forms: absolute and functional ID. Both forms of ID can manifest either isolated or combined, and will result in iron-deficient erythropoiesis and, if unrecognized or left untreated, in anemia $[1,2]$.

Absolute ID, as defined by a decrease in the body's iron content, usually develops when the absorption of dietary iron in the duodenum and proximal jejunum (Fig. 1a) cannot compensate for an increased iron demand or blood loss. Despite adaptive induction of expression of the transmembrane iron transporters divalent metal transporter (DMT)-1 and ferroportin (FPN)-1 in enterocytes upon ID, iron absorption can only be increased by 2- to 3-fold to approximately $5 \mathrm{mg}$ per day $[3,4]$. Due to this relatively inef- 


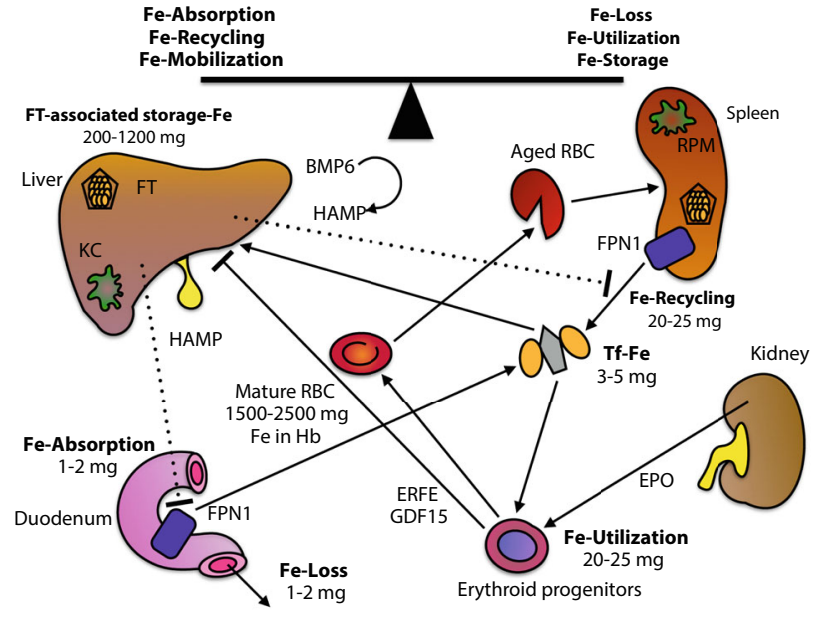

a

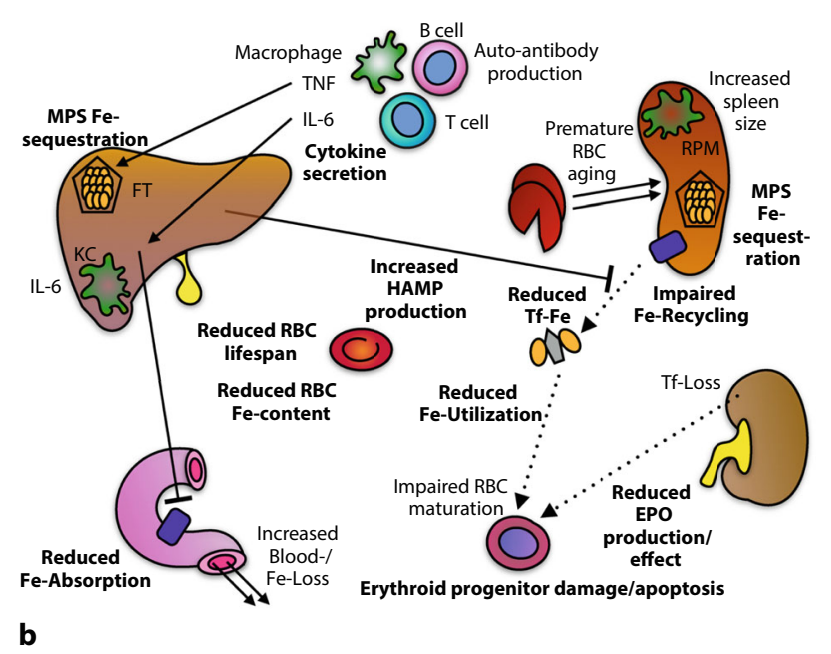

b

Fig. 1 a Under homeostatic conditions, the absorption of 1-2 mg of iron per day compensates for its loss via desquamation of epithelial cells from skin and mucosal membranes and during menstrual bleeding. The majority of the $20-25 \mathrm{mg}$ of iron required for daily erythropoiesis is provided by the degradation of effete $\mathrm{RBC}$ and the iron contained within their $\mathrm{Hb}$ (Hemoglobin). Both duodenal iron absorption and iron recycling in spleen and liver are negatively regulated by HAMP (Hepcidin antimicrobial peptide). HAMP is mainly generated by hepatocytes in response to an increase in serum iron or storage iron while erythropoietic activity inhibits HAMP expressionvia solublemediators including GDF15 and ERFE. bFollowing immuneactivation by pathogen-or damage-associated molecular patterns, the interaction of myeloid cells with $T$ and B lymphocytes results in the generation of pro- and anti-inflammatory cytokines. These divert iron fluxes from the circulation to storage sites by controlling the expression of HAMP, of iron transporters, and of the ironstorage protein FT. Therefore, duodenal iron absorption and macrophage iron recycling are reduced, the serum becomes iron-starved and the erythron lacks sufficient iron for proliferation and hemoglobin synthesis. Therefore, zinc may replace iron as the central hemecation. Zinc protoporphyrin-IX (not depicted) can be measured to confirm the presence of this mechanism of iron sequestration. In addition to cytokines, other mediators such as auto-antibodies and reactive intermediates can tag mature RBC for degradation or damage themor their precursors, contributing to the hyporegenerativenature of AI. In parallel, renalEPO production is reduced and the responsiveness of the erythron to EPO is dampened. In theend, a mild to moderate normocytic anemia with evidence of iron-restricted erythropoiesis (low TSAT, high FT, low reticulocytes, high ZnPP-IX in reticulocytes, low to normal EPO) occurs. Key pathways for the pathogenesis are in boldface. Putative additional pathways are in lightface. BMP6 bone morphogenetic protein-6, ERFE erythroferrone, EPO erythropoietin, FPN1 ferroportin-1, FT ferritin, GDF15 growth differentiation factor-15, HAMP hepcidin anti-microbial peptide, IL interleukin, KC Kupffer cell, MPS mononuclear phagocyte system, $P D G F$-BB platelet-derived growth factor isoform BB, $R B C$ red blood cell, $R P M$ red pulp macrophage, $T f$-Fe transferrin-bound iron, $T N F$ tumor necrosis factor, ZnPP-IXzinc protoporphyrinIX

ficient process, iron stores, particularly ferritin-associated iron in liver and spleen, can become depleted during chronic bleeding episodes, repetitive blood donations, helminth infestations, through materno-fetal transfer, or during growth [5].

In very rare cases, genetic mutations of iron homeostasis proteins such as DMT1 or TMPRSS6 (Transmembrane Protease, Serine 6), the latter encoding for matriptase-2, can result in inadequate iron absorption and development of anemia [6,7]. Similarly, lack of the iron-carrying serum protein transferrin (TF), due to genetic deficiency, auto-antibody production, or proteinuria, can cause absolute ID [8]. Inadequate iron absorption has also been found in association with Helicobacter pylori infection, hypergastrinemia, celiac disease, or vitamin D deficiency $[9,10]$. Prolonged ID results in the inability to regenerate skin and mucosal membranes and in iron deficiency anemia (IDA) with its classical symptoms such as fatigue. Details on the clinical implications of ID are reviewed elsewhere in this special issue.

Functional ID has a more complex pathophysiology and is commonly defined as a redistribution of iron from the key sites of its utilization (erythron, epidermis, mucosal surfaces) to storage sites, particularly the hepatic and splenic mononuclear phagocyte system (MPS). Moreover, in states of increased erythropoiesis such as during therapy with erythropoiesis-stimulating agent (ESA) or after major blood loss, erythropoiesis may become iron-restricted so long as the mobilization of storage iron cannot catch up with its demand for hemoglobin $(\mathrm{Hb})$ synthesis (see the interpretation of $\mathrm{CHr}$ (Content of reticulocyte hemoglobin), HYPO (Hypochromic erythrocytes), and ZnPP (Zinc protoporphyrin) in diagnostic section). The ultimate consequence of these functional disturbances of iron homeostasis is anemia, which is often referred to as anemia of inflammation (AI) or anemia of chronic disease (ACD).

Absolute and functional iron deficiency may also coexist. Such combined conditions render the interpretation of erythrocyte indices and parameters of iron status challenging. While new diagnostic parameters are not yet readily used in clinical routine, this differential is important as the therapeutic approach varies. In addition, the random detection of AI during 

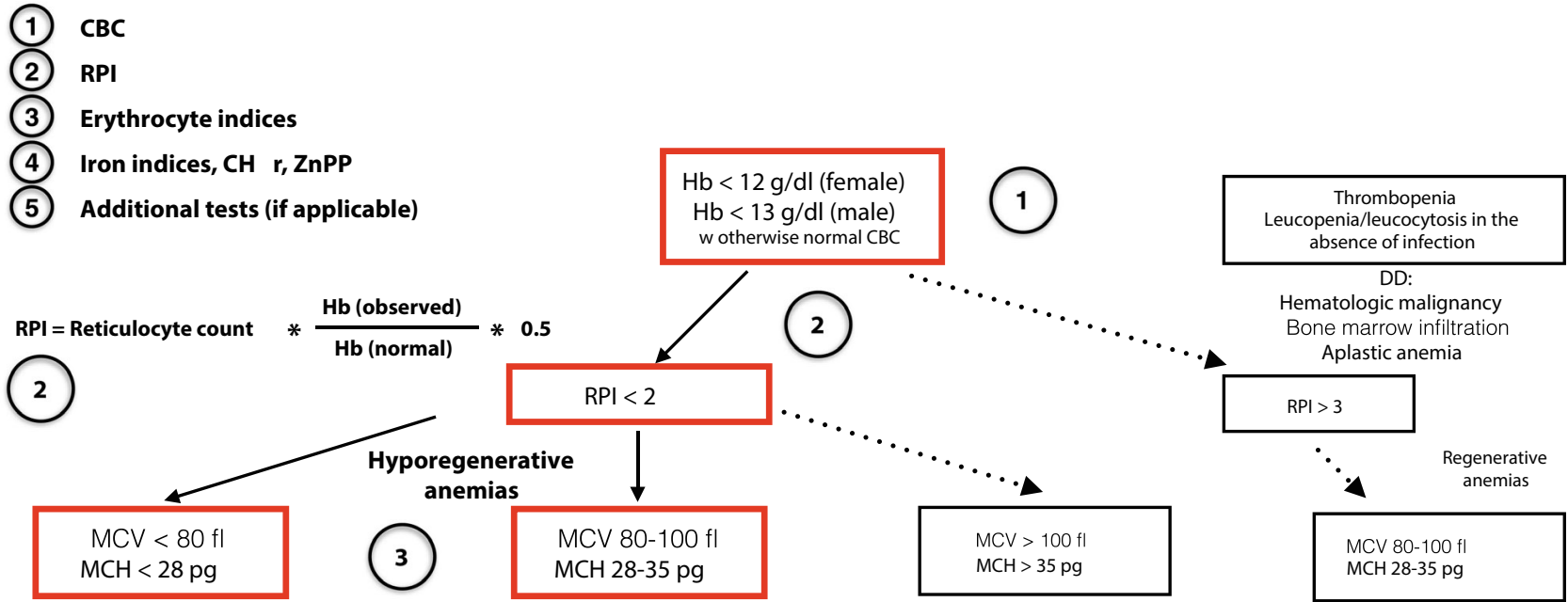

Hyporegenerative

Hyporegenerative

Hyporegenerative

Regenerative microcytic hypochromic anemia normocytic normochromic anemia

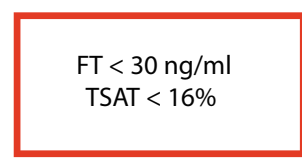

IDA

DD:

Al
Al+IDA

Familial sideroblastic anemia

Vitamin A-deficiency

Aluminium intoxication

Lead intoxication

Note: Reference ranges may vary

between countries, laboratories

and assays

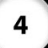

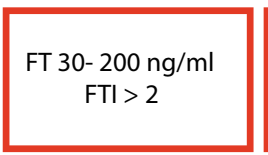

Al + IDA

FTI $=$ sTFR $/ \log F$

r

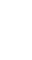$$
\text { Renal anemia (GFR, EPO) }
$$$$
\text { Cardio-renal anemia syndrome }
$$$$
\text { Anemia due to colderly }
$$$$
\text { nuia due to combined }
$$
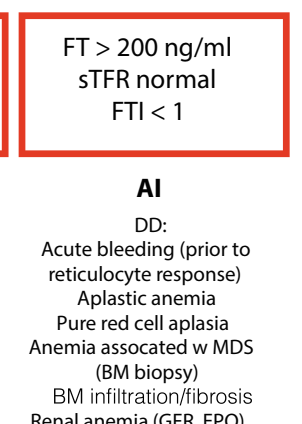$$
\text { BM infiltration/fibrosis }
$$
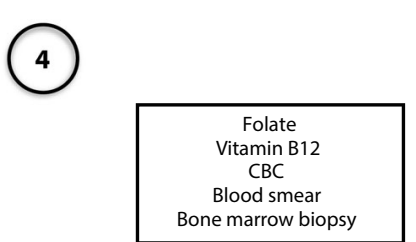

DD:

Folate deficiency

Vitamin B12 deficiency

MDS (BM biopsy)

Bone-marrow toxicity (BM biopsy)

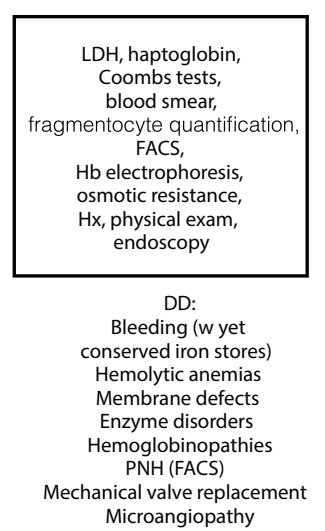

Fig. 2 For the differential diagnosis of IDA vs. Al vs. a combination of both forms or other causes of anemia, a stepwise approach is proposed. A CBC enables the differentiation of isolated anemias from bi- and pancytopenias [161]. The latter may require a more extensive work-up. Also, the RPI can be estimated from the CBC. An RPI of $<2$ characterizes hyporegenerative anemias while am RPI $>3$ is observed in regenerative forms such as the hemolytic anemias. Two out of three erythrocyte indices are relevant, i. e., the MCV and the $\mathrm{MCH}$, as they allow for the classification of microcytic hypochromic, normocytic normochromic, and makrocytic hyperchromic anemias. In IDA, both serum FT and TSAT are reduced. In contrast, an increased FT is typical of Al. In combined conditions, the FTI, as calculated from the serum TFR divided by the logarithmic serum FT, continues to be helpful for the differential diagnosis. In the future, novel parameters such as HAMP may be incorporated into diagnostic algorithms. Note: Reference ranges may vary between countries, laboratories, and assays. $\mathrm{Hb}$ cutoffs correspond to WHO definitions. $A /$ anemia of inflammation, $B M$ bone marrow, $C B C$ complete blood count, $D D$ differential diagnosis, EPO erythropoietin, GFR glomerular filtration rate, FACS fluorescence activated cell sorting, $F T$ ferritin, $F T /$ ferritin index, $H b$ hemoglobin, $H x$ history, IDA iron-deficiency anemia, $L D H$ lactate dehydrogenase, $M C H$ mean corpuscular hemoglobin, $M C V$ mean corpuscular volume, $M D S$ myelodysplastic syndrome, $P N H$ paroxysmal nocturnal hemoglobinuria, $R P$ I reticulocyte production index, sTFR soluble transferrin receptor, TSAT transferrin saturation

routine blood sampling should prompt a search for the underlying disease.

\section{Iron deficiency anemia}

While IDA poses a major public-health problem in developing countries [11], it is also frequently observed in industrialized countries: in $5-10 \%$ of individuals, as detailed elsewhere in this special issue. Isolated IDA can be detected by a complete blood count, and iron status based on the reticulocyte count or reticulocyte production index (RPI), erythrocyte indices, ferritin (FT), and transferrin saturation (TSAT). Typi- cally, IDA is an isolated hyporegenerative microcytic hypochromic anemia, with reduced FT concentration and TSAT as indicators of a depletion of iron stores and serum iron, respectively [12-15]. The RPI can easily be estimated by one of two established formulas (Fig. 2).

ID results in difficulties regenerating epidermis and mucosal epithelia, while also affecting the clinical course of associated chronic diseases. For instance, ID has negative effects on mitochondrial respiration and tissue oxygen consumption and, thus, on cardiac function and the clinical course of congestive heart failure (CHF) [16-18]. The importance of anemia for 
CHF is underscored by a linear increase of mortality with declining Hb levels [19-21]. Likewise, parenteral iron substitution has been found to improve the clinical course of $\mathrm{CHF}$ in patients with coexisting ID [22-24].

\section{Anemia of inflammation}

AI can be viewed as a spectrum of acute and chronic forms of anemia whose common pathophysiological denominator is their occurrence as a result of immune activation [25, 26].

Acute and chronic infections, inflammatory disorders, and malignancies are the principal disease types underlying AI. However, AI shares features with the renal anemia observed in patients with chronic kidney disease (CKD), the anemia in patients with chronic obstructive pulmonary disease (COPD), the anemia in patients with $\mathrm{CHF}$ without or with cardio-renal syndrome, and the anemia of the elderly [23, 27, 28].

The anemia of critical illness occurring after acute events such as major surgery, severe trauma, myocardial infarction or sepsis may be classified as a specific acute form of AI. Moreover, some features of AI also characterize the anemias occurring in hematologic disorders such as multiple myeloma or malignant lymphoma [29-32].

In addition, combined forms of IDA and AI may be present. This scenario is typically observed in inflammatory bowel disease (IBD) or gastrointestinal or urogenital malignancy. Mucosal erosions and ulcerations are associated with recurrent bleeding episodes and lead to a substantial loss of iron, since $0.5 \mathrm{mg}$ of iron are contained within the $\mathrm{Hb}$ of $1 \mathrm{ml}$ of blood. At the same time, the underlying disease provides an inflammatory stimulus for the sequestration of iron in the MPS. Moreover, menstruation, hemodialysis, the requirement for repetitive blood sampling, and anticoagulant or antiplatelet drugs may contribute to iron loss in CKD and other chronic diseases.

\section{Multiple players in the pathophysiology of Al}

\section{Immune cells}

The activation of immune cells by infectious agents, auto-antigens, or neoplastic cells initiates and maintains the development of AI by several mechanisms which coexist and are cross-regulatory (Fig. 1b). The excessive production of inflammatory mediators diverts iron to the MPS, rendering it relatively unavailable for erythroid progenitors [33]. A paradigm for such a mediator is hepcidin anti-microbial peptide (HAMP). HAMP is the hormonal negative-feedback regulator of serum iron, as it limits iron-fluxes to the circulation. Upon iron excess or inflammation, HAMP is produced by hepatocytes and, in much smaller quantities, by immune cells and other cell types. HAMP's specific receptor is FPN1, whose only known function is to act as an export protein for ionic iron. Binding of HAMP to FPN1 tags the latter for internalization from the cell membrane and for lysosomal degradation [34].

Activation of pattern recognition receptors such as Toll-like receptor (TLR)-4, as well as pro- and antiinflammatory cytokines regulate HAMP expression, while similar pathways control transcriptional expression of iron transporters transferrin receptor (TFR)-1, DMT1, and FPN1, as well as the iron storage protein FT [26].

For instance, lipopolysaccharide as a component of the Gram-negative cell wall enhances HAMP production while stimulating DMT1 expression in myeloid cells, thereby favoring iron sequestration [35]. In parallel, interleukin (IL)-10 increases TFR1 and FT transcription, which may aggravate $\mathrm{AI}$ in patients with IBD [36].

Increased HAMP levels are also well documented in infections, rheumatoid disorders, and IBD. Furthermore, in almost all patient cohorts, HAMP concentration positively correlates with disease activity linking the extent of inflammation to the severity of iron sequestration in the MPS [37-43].

\section{Liver}

The liver is a key organ initiating and maintaining AI [12]. Hepatocytes are the key source of HAMP, while Kupffer cells (KC) are a major site of inflammationdriven iron storage. Interestingly, KC dampen HAMP production in homeostatic conditions but may be required for inflammation-driven HAMP secretion $[44,45]$. IL- 6 is essential for the up-regulation of HAMP upon inflammation and IL-6 blockade for the treatment of rheumatoid arthritis lowers both disease activity and circulating HAMP levels [46, 47]. $\mathrm{TF}$ is a major product of hepatocytes and one of a limited number of negative acute phase reactants. IL-6 and other pro-inflammatory cytokines result in a downregulation of TF expression in the liver, thus reducing the serum's capacity to transport iron [48]. This mechanism may additionally contribute to iron sequestration in the MPS. Since TF-bound iron and TFR1 form the key mechanism of iron uptake for erythroid progenitors, a central role for the development of AI is implicit. TFR1 is also expressed by neoplastic cells in solid tumors and hematologic malignancies, including chronic lymphocytic leukemia, suggesting that inflammation associated with malignant diseases may also limit iron availability for cancer cells [49, 50]. However, potential functional consequences for tumor-associated monocytes/macrophages (TAM) are not sufficiently addressed. In addition, several pathogens are able to acquire TF-bound iron [51-54]. Therefore, the reduction of serum TF appears to be one of the mechanisms of microbial iron withdrawal [54-57]. 
Serum iron (TF-bound iron), the amount of stored iron (FT-stored iron), and the iron demand for erythropoiesis are key variables that are integrated by hepatocytes to adapt HAMP production to current metabolic needs. Serum iron levels are sensed by a machinery involving TFR1, TFR2, and the hemochromatosis-associated HFE protein [58]. However, in being the primary iron source for erythropoiesis, TF also indirectly regulates HAMP expression via erythroid progenitor-derived mediators, suggesting that the pathways of HAMP regulation are interconnected [59-61].

An increase in the erythropoietic activity as observed after blood loss or erythropoietin (EPO) administration suppresses HAMP production [62]. Part of this effect may be mediated via erythroferrone (ERFE), a lack of which delays the recovery from $\mathrm{AI}$ in a mouse model [63]. Growth-differentiation factor (GDF)-15, whose levels are increased in thalassemia and AI with or without ID, also inhibits HAMP expression [60, 64]. Hypoxia has a similar effect on HAMP that is mediated via platelet-derived growth factor isoform BB (PDGF$\mathrm{BB})$, which may enable the required increase of $\mathrm{Hb}$ levels at high altitude [65].

Iron accumulation in the liver induces bone morphogenetic protein (BMP)-6, which is essential to maintain body iron homeostasis. BMP6 binds to a heterodimeric receptor complexed with hemojuvelin (HJV) and matriptase-2 (the gene product of TMPRSS6), and stimulates HAMP expression [66, 67]. Notably, BMP6 is primarily produced by nonparenchymal liver cells and may act in a paracrine manner on adjacent hepatocytes [68].

In the context of inflammation, IL- 6 and IL-22 stimulate HAMP expression via specific receptors signaling through signal transducer and activator of transcription (STAT)-3, while alpha-1 antitrypsin may do so via HJV and matriptase-2 [69-71]. However, inflammation also feeds into the BMP6 signaling pathway, adding further complexity; not only to the regulation of iron homeostasis, but also to the pathophysiology of AI and the clinical interpretation of iron indices [72].

In their reproductive years, women have an increased iron demand. Estradiol, whose levels increase after menstrual bleeding during the first half of the menstrual cycle (follicular phase) until ovulation, inhibits HAMP transcription in hepatocytes, which may allow for higher intestinal iron absorption to compensate for the average $20-80 \mathrm{ml}$ of monthly menstrual blood loss [73, 74]. In contrast, progesterone, which rises after ovulation and dominates the second half of the cycle (luteal phase) until menstrual bleeding, rather stimulates HAMP expression [75]. Given the resulting fluctuations of HAMP and iron indices, the last five days of the menstrual cycle have been proposed for blood sampling to allow for a more representative evaluation of iron status in women [76].
Recently, the concept has emerged that drugs may have undesired side effects on iron homeostasis, since the mTOR inhibitor rapamycin may increase HAMP levels after heart transplantation, thus inducing a functional ID and anemia [77].

\section{Spleen}

The spleen contributes to the pathogenesis of AI as site of iron retention in macrophages. Furthermore, splenomegaly may result in hypersplenism and a reduced half-life of red blood cells (RBC) as a consequence of the increased RBC elimination by red pulp macrophages (RPM). Similarly, evidence from mouse models suggests that increased erythrophagocytosis contributes to the rapid $\mathrm{Hb}$ drop in acute and subacute forms of AI [78, 79]. Under conditions of excessive inflammation as seen in sepsis patients, reactive oxygen intermediates may further accelerate RBC damage and their removal by complement-dependent mechanisms [80, 81].

\section{Kidney}

While hepatic HAMP formation is increased during inflammation, EPO production in the kidney is subject to inhibition by inflammatory mediators such as tumor necrosis factor (TNF) and IL-1 [82-84].

CKD with a glomerular filtration rate $(\mathrm{GFR})<40 \mathrm{ml} /$ $\mathrm{min} / \mathrm{m}^{2}$ results in insufficient or deregulated production of EPO and of 1, 25-dihydroxy-cholecalciferole, both of which are negative regulators of HAMP [85, 86]. Theoretically, for the assessment of whether the renal EPO response is adequate in AI, the EPO concentration as measured should be corrected for the actual $\mathrm{Hb}$ level (comparable to RPI for the correction of reticulocyte counts). However, no consensus exists on a correction formula for EPO for subjects with normal renal function or for CKD patients [84, 87].

Independently, glomerulopathy may result in proteinuria and the loss of the $80-\mathrm{kD}$ serum protein $\mathrm{TF}$, which is the major shuttle between compartments of iron absorption (intestine)/iron recycling (MPS) and the erythron. While isolated antibodies to TF may lead to IDA, such auto-antibodies have not yet been reported in systemic autoimmune diseases. However, it is known that a functionally distinct type of antiTF antibodies in monoclonal gammopathies may result in hyperferritinemia and increase of hepatic iron storage [88, 89].

\section{Erythron}

A resistance of the erythron to EPO is another mechanism underlying AI, since it reduces the erythropoietic drive even in the setting of normal or adequately increased serum EPO concentrations. Part of this may be attributed to downregulation of the EPO receptor on erythroid cells by interferon (IFN) $-\gamma$ [90]. Further- 
more, a range of inflammatory mediators including TNF, IL- 1 , IFN- $\gamma$, and reactive intermediates inhibits the proliferation and differentiation of erythroid progenitors or induces their apoptosis [91-94]. These pathways ultimately culminate in an insufficient renal EPO response and hematopoietic EPO resistance further aggravating anemia in AI [95].

Numerous infectious agents (e.g., parvovirus B19 and human herpes virus-6) and neoplastic cells may infiltrate the bone marrow, which eventually disturbs erythropoiesis by several mechanisms, including direct damage to erythroid cells and putative negative effects on the microenvironment and the stem cell niche. In addition, there may be direct toxic effects of drugs including chemotherapeutics and of radiation therapy on hematopoietic stem/progenitor cells. Cytopenia, including anemia, is a concern of methotrexate treatment for rheumatoid arthritis [96]. However, immunological deregulation induced by biologics such as anti-TNF therapy may also induce aplastic anemia [97].

While in its classical form AI constitutes a hyporegenerative anemia, hemolysis may contribute to the development of AI or aggravate its degree in several settings. For instance, several bacteria including Staphylococcus aureus produce hemolysins [98]. These destroy RBC, liberating heme for its uptake into bacteria by specific receptors. Different mechanisms of heme iron acquisition are exploited by intraerythrocytic infectious agents such as Plasmodium [99]. In addition, malaria induces HAMP, suggesting that iron sequestration is a major contributing factor to malarial anemia [100, 101]. Elevated HAMP levels have also been reported in patients with HIV (Human immunodeficiency virus) infection, in which they are associated with anemia and independently predict mortality [102]. While auto-antibodies against RBC can be induced by acute Epstein-Barr virus and Mycoplasma pneumoniae infections resulting in cold agglutinin disease, auto-immune hemolysis may also occur in the setting of chronic infections or as a side effect of medication [103]. In addition, the life span of circulating RBC may be negatively affected by inflammatory mediators such as TNF and by mechanical stress [104]. Therefore, hemolysis may also contribute to AI in conditions such as CHF associated with mechanical valve replacement or endocarditis, or when microangiopathy is present. However, due to fluid retention, the degree of anemia tends to be overestimated in CHF patients.

\section{Others}

Similar to the concurrent presence of absolute ID in the setting of AI, deficiencies in other nutrients essential to erythropoiesis, such as folate and vitamin B12, may be contributory. For instance, celiac disease may cause profound malassimilation of various nutrients or poor food intake may aggravate the anemia of the elderly. Particularly in elderly patients, anemia due to clonal hematopoietic diseases, including myelodysplastic syndromes (MDS), has to be considered as well.

\section{Current and promising diagnostic tools}

\section{Complete blood count, reticulocyte production index, and red blood cell indices}

Both IDA and AI typically manifest as isolated anemia. As detailed elsewhere in this special issue, both absolute ID and inflammation can also result in thrombocytosis due to the effects of altered thrombopoietin, EPO, and IL-6 levels on megakaryopoiesis [105-107]. In addition, the disorders underlying AI or the immune-modulatory therapy required for their control can affect circulating leukocyte numbers [108]. A differential blood count can be recommended for unclear cases of anemia where monoclonality may be suspected as an underlying disease (Fig. 2). Serum protein electrophoresis and bone marrow aspiration or trephine biopsy may reveal additional diagnostic clues. The reticulocyte count allows for the differentiation of hyporegenerative anemias (disorders of erythroid proliferation and maturation) vs. regenerative anemias (hemolysis or hemorrhage). However, to account for the increased proportion of reticulocytes in anemia and the increased presence of prematurely released reticulocytes in the circulation, the RPI should be calculated (Fig. 2).

Erythrocyte staining indices do not define the cause of anemia, but they may be helpful during the diagnostic workup. IDA is a microcytic hypochromic anemia, while AI may be microcytic hypochromic or normocytic normochromic in appearance. High normal to elevated MCV and MCH may be due to a complex metabolic disorder (e.g., in alcoholism), severe nutrient deficiency (e.g., in celiac disease), or an alternative diagnosis such as MDS.

In addition, clinical signs along with the measurement of TSH (Thyroid stimulating hormone) and PTH (Parathyroid hormone) will help to rule out endocrine disorders (specifically hyperthyroidism, hypothyroidism, panhypopituitarism, and hyperparathyroidism) as the cause of a hyporegenerative, normocytic normochromic anemia.

\section{Ferritin and transferrin saturation}

In IDA, serum FT and TFS may enable an accurate interpretation of body iron status. A reduction in serum FT below $30 \mathrm{ng} / \mathrm{ml}$ shows ID with high diagnostic accuracy because a strong correlation exists between serum FT and the body's total iron storage. It is generally assumed that for each $1 \mathrm{ng} / \mathrm{ml}$ of serum FT, $10 \mathrm{mg}$ of iron are stored in tissues and organs. Serum FT appears to be iron-poor and mainly derived from macrophages [109]. 
Serum FT levels in the setting of inflammation are more difficult to interpret as a range of stimuli result in altered production of FT. Therefore, the clinical presentation, along with markers of inflammation such as C-reactive protein or IL-6, needs to be taken into account. The appearance of hyperferritinemia $>200 \mathrm{ng} / \mathrm{ml}$ in the context of a decreased TSAT is suggestive of immune-driven iron sequestration. This may be indicative of inflammation, cancer, infection, or liver disease. Extraordinarily high FT levels have been documented in patients with adult-onset Still's disease or hemophagocytic syndrome $[110,111]$.

In an attempt to transport the available iron as efficiently as possible, serum TF is increased in ID, resulting in a TSAT $<16 \%$. Similar levels are observed in AI because TF is a negative acute-phase reactant (see above).

Hyperferritinemia in the context of an increased TSAT of $>45 \%$ should prompt evaluation for primary or secondary iron overload. In the context of microcytic anemia and Mediterranean or Asian descent, thalassemia is a valid differential diagnosis. In the absence of anemia, HFE-associated hemochromatosis or dysmetabolic iron overload are possible explanations for pathologically increased FT and TSAT.

\section{Soluble transferrin receptor and ferritin index}

TFR1 is the key receptor for iron acquisition by erythroid cells. Its soluble form (sTFR) can be measured in the serum and it reflects ID and erythropoietic activity. sTFR is increased in ID, hemolytic anemias, thalassemia, and some hematologic malignancies, while its levels tend to be normal in AI [112]. Therefore, an increased STFR in the setting of AI suggests the presence of additional absolute ID. However, the use of sTFR is limited by the lack of its standardization and the fact that age, ethnicity, and inflammation influence its normal range [113].

The ferritin index (FTI) may also be helpful in the differential diagnosis of AI and combined IDA/AI. However, the lack of standardized tests for sTFR prevents its broad recommendation. The FTI is calculated from the sTFR divided by the logarithm of serum FT (Fig. 2). In patients with chronic diseases and AI, an increased FTI suggests the concurrent presence of absolute ID requiring correction. However, the cutoff value is largely dependent on the specific diagnostic test used [114-116]. Therefore, at the current stage of research we are unfortunately not able to provide a universally applicable algorithm for the differentiation between isolated AI and anemia with combined functional and absolute ID.

\section{Content of reticulocyte hemoglobin, percent of hypochromic erythrocytes, and zinc protpoporphyrin}

Content of reticulocyte hemoglobin $(\mathrm{CHr})$, percent of hypochromic erythrocytes (\%HYPO), and zinc proto- porphyrin (ZnPP) allow for the prediction of iron availability for erythropoiesis, but have little to no role in the differentiation between IDA and AI.

The content of $\mathrm{Hb}$ in reticulocytes correlates with the availability of iron for erythropoiesis. A CHr $<26$ pg suggests iron-limited erythropoiesis, as observed in both IDA and AI. In response to iron substitution, it is one of the first parameters to respond with an increase. A lack of this predicted response raises the concern of an alternative diagnosis, unless CKD is present and EPO deficiency awaits correction.

HYPO is defined as the relative number of hypochromic $\mathrm{RBC}$ with a Hb content $<28 \mathrm{pg}$. A HYPO $>10 \%$ indicates iron-deficient erythropoiesis due to IDA or AI.

As erythropoiesis becomes iron-deficient, the erythroid enzyme ferrochelatase incorporates zinc instead of iron into protoporphyrin-IX. Since ZnPP and heme are analogues, an increase in the ratio of $\mathrm{ZnPP} /$ heme indicates ID for erythropoiesis and is observed in IDA, AI, MDS, and sideroblastic anemias, including the form secondary to lead intoxication [117]. This highlights the lack of specificity of this set of parameters for the differential diagnosis of anemias.

\section{Hepcidin and its regulators}

Hepcidin (HAMP) may be helpful in the differential diagnosis of anemias, as well as in the assessment of therapeutic options. For instance, HAMP is suppressed in IDA, in the normal range in IDA/AI, and elevated in AI $[112,118]$. High HAMP at the time of initiation of therapy with ESA may predict poor treatment response in AI [119]. In addition, high HAMP predicts poor response to oral iron in IDA patients [120]. In CKD patients, the predictive power of HAMP for the indication for iron therapy is limited [43, 121, 122]. Attempts have been undertaken to harmonize the different diagnostic methods for hepcidin determination to allow the broad clinical use of this method [123]. GDF15 is normal in IDA and elevated in AI and IDA/AI [64].

In the future, information technology may provide us with software based on complex algorithms for a more accurate assessment of iron status and, just as importantly, guide therapy for the most appropriate treatment. For instance, we may witness that mobile applications based on a combined panel of HAMP, EPO, ERFE, GDF15, BMP6, and other parameters, such as high sensitive CRP and IL-6, enter clinical routine.

\section{Treatment options}

Since the AI is a direct consequence of an active immune-driven disease, its first-line therapy is treatment of the underlying condition. However, the subsequent therapeutic approach to AI remains a matter of debate and ongoing clinical trials. Iron supplementa- 
tion, ESA, and transfusion of packed RBC are the current specific treatment options for AI.

It is generally assumed, similar to the hypoferremia of the acute phase response, that AI is the pathophysiological consequence of the body's attempt to reduce the availability of iron for infectious agents. Therefore, there is the concern that iron supplementation may stimulate pathogen proliferation or result in a flare of an underlying inflammatory disorder or malignancy [54, 124, 125]. Similarly, ESA and RBC transfusions may have adverse immune-modulatory effects [126-129]. The target therapeutic Hb levels have not yet been defined in prospective trials; however, data from studies in patients with anemia and CKD or cancer suggest a slightly anemic target range between 11-12 g/dl to be safe [130, 131].

\section{Iron preparations}

Isolated IDA can often be prevented by iron fortification/supplementation and, once it has manifested, is preferentially treated by oral iron salts. For instance, approximately $100 \mathrm{mg}$ of elemental iron contained in 300-350-mg ferrous sulfate preparations can be prescribed as a daily dose. These iron salts are absorbed by the sequential action of DMT1 and FPN1 and associated oxidoreductases, but have a low bioavailability. However, products using heme rather than ionic iron have entered the market. These are absorbed by alternative pathways that are incompletely characterized, since the proposed solute carrier SLC46A1 absorbs folate more efficiently than heme [132, 133]. A recent study in non-anemic young women with ID has shown that a single morning dose of 40-80 mg ferrous sulfate resulted in adequate iron absorption yet elicited a transient rise in serum HAMP levels, which argues against twice-daily dosage. Whether or not alternate day supplementation provides a benefit awaits investigation in prospective trials [134].

Parenteral iron supplementation is an alternative to consider, especially when a rapid correction is needed, or gastrointestinal (GI) malassimilation or active inflammatory disease dampens dietary iron absorption in AI $[135,136]$. Also, in patients with intolerance to oral iron supplements, parenteral iron is the therapy of choice. Currently, six different forms of parenteral iron are available for clinical use, i. e., ferric carboxymaltose, ferumoxytol, iron dextran, iron gluconate, iron isomaltoside, and iron sucrose. These represent macromolecules in which iron is complexed to saccharides. The complexes are endocytotically taken up by the MPS and ionic iron is distributed into the circulation via FPN1 by macrophages [137]. Concerns have been raised regarding the risk of severe anaphylactic reactions when using intravenous iron preparations. However, these are infrequent and specific precautions are recommended in at-risk patients, to minimize the occurrence of such adverse events [138]. In addition, parenteral iron supplements harbor an in- trinsic risk of inducing hypophosphatemia. Therefore, serum phosphate may be measured when erythropoietic and iron indices are determined to evaluate the response to treatment [139].

Despite the fact that the MPS has a lower threshold to respond to increased HAMP than have duodenal enterocytes, parenteral iron remains effective when intestinal iron absorption is hampered by immune activation [140]. Since parenteral iron stimulates HAMP secretion, as documented in hemodialysis patients, frequent administration of low doses may be beneficial [141]. Prospective trials are required to optimize treatment regiments to ensure adequate efficiency of parenteral supplementation in different clinical settings.

In the context of $\mathrm{AI}$, parameters which predict the subsequent response to EPO therapy are being evaluated in prospective studies. In CKD patients, iron therapy is specifically recommended to replenish stores prior to initiation of ESA therapy. TSAT $<20 \%$ and FT $<100 \mathrm{ng} / \mathrm{ml}$ have been proposed as cutoffs for absolute ID in non-dialysis CKD patients [142]. Further details are reviewed elsewhere [130].

\section{$E S A$}

Currently, the arm of therapy with ESA remains limited to EPO analogues, as the synthetic EPO receptor agonist peginesatide has been taken off the market because of rare anaphylactic reactions [143].

Many subjects with AI who are under causative treatment for their underlying condition do not have an adequate $\mathrm{Hb}$ response to iron therapy. EPO resistance of the erythron or renal EPO deficiency may be present, such that ESA should be considered as add-on therapy for anemia. Specific studies have been conducted in patients with $\mathrm{AI}$ in the setting of rheumatoid arthritis or HIV infection, in which EPO levels $<500 \mathrm{U} / \mathrm{L}$ predicted a response to ESA administration [144, 145]. Standard starting doses of EPO are 100-150 U/kg, administered subcutaneously three times a week, although higher doses may be required for individual patients. As $\mathrm{Hb}$ levels increase during efficient EPO therapy, iron parameters should be monitored and iron supplemented in order to maintain a TSAT $\geq 20 \%$ and a FT $\geq 100 \mathrm{ng} / \mathrm{ml}$ for a sufficient $\mathrm{Hb}$ response. In dialysis patients, higher FT target levels have been suggested [146]. In MDS, ESA are in wide clinical use despite of the fact that official approval of this approach is still pending [147]. The specific regimes and pitfalls in ESA therapy are reviewed elsewhere [130, 131, 148, 149].

\section{The HAMP-FPN1 axis as target}

Given its important role for iron-sequestration in AI, HAMP and its receptor FPN1 are attractive targets for therapeutic interventions. Different pharmaceutical preparations including antibodies, an- 
tichalins, Spiegelmers, thiamine derivatives, and heparin derivatives can bind and neutralize HAMP [150, 151]. Moreover, direct blockage of HAMP expression via SHJV or BMP signaling inhibitors have shown efficiency in blocking HAMP function and ameliorating anemia [152]. Some of these treatments are already being evaluated in clinical trials [153-158]. Moreover, an FPN1 stabilizing antibody is currently also under investigation [159].

Since the HIF-EPO axis forms an alternative targetable pathway, prolyl hydroxylase inhibitors have entered clinical trials. This class of drugs can be orally administered and protects HIF from degradation, which increases EPO levels and erythropoietic iron availability [160].

\section{Summary}

The precise differential diagnosis between IDA, AI, and a combination of both forms is of clinical importance because of differing treatment strategies. Currently, the lack of data from prospective clinical trials prevents definitive recommendations on diagnostic algorithms and prognostic indices. These problems are aggravated by the lack of standardization in otherwise promising tests, such as measurement of sTFR. However, within the next few years, standardized tests for novel parameters such as HAMP or ERFE will become available for more accurate differential diagnosis, stratification of treatment indications, and prediction of therapeutic response. Furthermore, the HAMP-FPN1 axis continues to receive a lot of attention as a therapeutic target. Blocking HAMP expression or processing, neutralization of circulating HAMP, and blockage of its interaction with FPN1 are under active investigation for the treatment of AI.

Moreover, different forms of AI may have to be taken into account. Dependent on the underlying conditions and dominant pathophysiological pathways, a more personalized approach to optimal management of distinct forms of anemias will be required.

Funding information This work was supported by grants from the Austrian Research Fund (FWF; project TRP-188 to G.W.; projects P28302-B30 and P24749-B13 to I.T.), the "Theodor Körner Fonds" (to M.N.), the intramural funding program of the Medical University Innsbruck for young scientists MUI-START (project 2012032003 to M.N.), and by the "Verein zur Förderung von Forschung und Weiterbildung in Infektiologie und Immunologie an der Medizinischen Universität Innsbruck".

Open access funding provided by University of Innsbruck and Medical University of Innsbruck.

Conflict of interest M. Nairz, I. Theurl, D. Wolf, and G. Weiss declare that they have no competing interests.

Open Access This article is distributed under the terms of the Creative Commons Attribution 4.0 International License (http://creativecommons.org/licenses/by/4.0/), which permits unrestricted use, distribution, and reproduction in any medium, provided you give appropriate credit to the original author(s) and the source, provide a link to the Creative Commons license, and indicate if changes were made.

\section{References}

1. Weiss G, Goodnough LT. Anemia of chronic disease. NEngl J Med. 2005;352:1011-23.

2. Theurl I, Fritsche G, Ludwiczek S, Garimorth K, BellmannWeiler R, Weiss G. The macrophage: a cellular factory at the interphase between iron and immunity for the control of infections. Biometals. 2005;18:359-67.

3. Rockey DC. Occult gastrointestinal bleeding. N Engl J Med. 1999;341:38-46.

4. Zoller H, Koch RO, Theurl I, et al. Expression of the duodenal iron transporters divalent-metal transporter 1 and ferroportin 1 in iron deficiency and iron overload. Gastroenterology. 2001;120:1412-9.

5. Hentze MW, Muckenthaler MU, Galy B, Camaschella C. Two to tango: regulation of Mammalian iron metabolism. Cell. 2010;142:24-38.

6. Kloss-Brandstatter A, Erhart G, Lamina C, et al. Candidate gene sequencing of SLC11A2 and TMPRSS6 in a family with severe anaemia: common SNPs, rare haplotypes, no causative mutation. PLoSONE. 2012;7:e35015.

7. Camaschella C. Iron-Deficiency Anemia. N Engl J Med. 2015;373:485-6.

8. Larrick JW, Hyman ES. Acquired iron-deficiency anemia caused by an antibody against the transferrin receptor. $\mathrm{N}$ EnglJ Med. 1984;311:214-8.

9. Perlstein TS, Pande R, Berliner N, Vanasse GJ. Prevalence of 25-hydroxyvitamin D deficiency in subgroups of elderly persons with anemia: association with anemia of inflammation. Blood. 2011;117:2800-6.

10. Hershko C, Patz J. Ironing out the mechanism of anemia in celiac disease. Haematologica. 2008;93:1761-5.

11. Kassebaum NJ, Jasrasaria R, Naghavi M, et al. A systematic analysis of global anemia burden from 1990 to 2010 . Blood. 2014;123:615-24.

12. Weiss G. Anemia of chronic disorders: new diagnostic tools and new treatment strategies. Semin Hematol. 2015;52:313-20.

13. Goodnough LT, Nemeth E, Ganz T. Detection, evaluation, and management of iron-restricted erythropoiesis. Blood. 2010;116:4754-61.

14. Thomas L, Franck S, Messinger M, Linssen J, Thome M, Thomas C. Reticulocyte hemoglobin measurement-comparison of two methods in the diagnosis of iron-restricted erythropoiesis. Clin Chem Lab Med. 2005;43:1193-202.

15. Archer NM, Brugnara C. Diagnosis of iron-deficient states. CritRev Clin Lab Sci. 2015;52:256-72.

16. Jankowska EA, Rozentryt P, Witkowska A, et al. Iron deficiency predicts impaired exercise capacity in patients with systolic chronic heart failure. JCard Fail. 2011;17:899-906.

17. Oexle H, Gnaiger E, Weiss G. Iron-dependent changes in cellular energy metabolism: influence on citric acid cycle and oxidative phosphorylation. Biochim Biophys Acta. 1999;1413:99-107.

18. Rensvold JW, Ong SE, Jeevananthan A, Carr SA, Mootha VK, Pagliarini DJ. Complementary RNA and protein profiling identifies iron as a key regulator of mitochondrial biogenesis. Cell Rep. 2013;3:237-45.

19. Ezekowitz JA, McAlister FA, Armstrong PW. Anemia is common in heart failure and is associated with poor outcomes: insights from a cohort of 12065 patients with new-onsetheartfailure. Circulation. 2003;107:223-5. 
20. Mozaffarian D, Nye R, Levy WC. Anemia predicts mortality in severe heart failure: the prospective randomized amlodipine survival evaluation (PRAISE). J Am Coll Cardiol. 2003;41:1933-9.

21. Horwich TB, Fonarow GC, Hamilton MA, MacLellan WR, Borenstein J. Anemia is associated with worse symptoms, greater impairment in functional capacity and a significant increase in mortality in patients with advanced heart failure. JAm Coll Cardiol. 2002;39:1780-6.

22. Ebner N, Jankowska EA, Ponikowski P, et al. The impact of iron deficiency and anaemia on exercise capacity and outcomes in patients with chronic heart failure. Results from the Studies Investigating Co-morbidities Aggravating Heart Failure. Int J Cardiol. 2016;205:6-12.

23. Silverberg DS. The role of erythropoiesis stimulating agents and intravenous (IV) iron in the cardio renal anemia syndrome. Heart Fail Rev. 2011;16:609-14.

24. Anker SD, Comin CJ, Filippatos G, et al. Ferric carboxymaltose in patients with heart failure and iron deficiency. $\mathrm{N}$ EnglJ Med. 2009;361:2436-48.

25. Metzgeroth G, Hastka J. Iron deficiency anemia and anemia of chronic disorders. Internist (Berl). 2015;56:978-88.

26. Weiss G. Iron metabolism in the anemia of chronic disease. Biochim Biophys Acta. 2009;1790:682-93.

27. Ferrucci L, Semba RD, Guralnik JM, et al. Proinflammatory state, hepcidin, and anemia in older persons. Blood. 2010;115:3810-6.

28. Boutou AK, Pitsiou GG, Stanopoulos I, Kontakiotis T, Kyriazis G, Argyropoulou P. Levels of inflammatory mediators in chronic obstructive pulmonary disease patients with anemia of chronic disease: a case-control study. QJM. 2012;105:657-63.

29. Maes K, Nemeth E, Roodman GD, et al. In anemia of multiple myeloma, hepcidin is induced by increased bone morphogenetic protein 2. Blood. 2010;116:3635-44.

30. Bordini J, Bertilaccio MT, Ponzoni M, et al. Erythroblast apoptosis and microenvironmental iron restriction trigger anemia in the $\mathrm{VK}^{*} \mathrm{MYC}$ model of multiple myeloma. Haematologica. 2015;100:834-41.

31. Hohaus S, Massini G, Giachelia M, etal. Anemiain Hodgkin's lymphoma: the role of interleukin- 6 and hepcidin. J Clin Oncol. 2010;28:2538-43.

32. Tisi MC, Bozzoli V, Giachelia M, et al. Anemia in diffuse large B-cell non-Hodgkin lymphoma: the role of interleukin-6, hepcidin and erythropoietin. Leuk Lymphoma. 2014;55:270-5.

33. Cazzola M, Ponchio L, Benedetti F de, et al. Defective iron supply for erythropoiesis and adequate endogenous erythropoietin production in the anemia associated with systemic-onset juvenile chronic arthritis. Blood. 1996;87:4824-30.

34. Nemeth E, Tuttle MS, Powelson J, et al. Hepcidin regulates cellular iron efflux by binding to ferroportin and inducing its internalization. Science. 2004;306:2090-3.

35. Ludwiczek S, Aigner E, Theurl I, Weiss G. Cytokinemediated regulation of iron transport in human monocytic cells. Blood. 2003;101:4148-54.

36. Tilg H, Ulmer H, Kaser A, Weiss G. Role of IL-10 for induction of anemia during inflammation. J Immunol. 2002;169:2204-9.

37. Masson C. Rheumatoid anemia. Joint Bone Spine. 2011;78:131-7.

38. Abdel-Khalek MA, El-Barbary AM, Essa SA, Ghobashi AS. Serum hepcidin: a direct link between anemia of inflammation and coronary artery atherosclerosis in patients with rheumatoid arthritis. J Rheumatol. 2011:38:2153-9.
39. Pakoz ZB, Cekic C, Arabul M, et al. An Evaluation of the Correlation between Hepcidin Serum Levels and Disease Activity in Inflammatory Bowel Disease. Gastroenterol Res Pract. 2015; doi:10.1155/2015/810942.

40. Mecklenburg I, Reznik D, Fasler-Kan E, Drewe J, Beglinger C, Hruz P. Serum hepcidin concentrations correlate with ferritin in patients with inflammatory bowel disease. J Crohns Colitis. 2014;8:1392-7.

41. Swellam M, Gabal KM, Youssef SS. Interleukin-1 receptor antagonist gene polymorphism and hepcidin in rheumatoid arthritis: Correlations with clinical and laboratory indices of disease activity. IUBMB Life. 2013;65:883-8.

42. Darton TC, Blohmke CJ, Giannoulatou E, et al. Rapidly Escalating Hepcidin and Associated Serum Iron Starvation Are Features of the Acute Response to Typhoid Infection in Humans. PLoS Negl Trop Dis. 2015;9:e0004029.

43. Kroot JJ, Tjalsma H, Fleming RE, Swinkels DW. Hepcidin in human iron disorders: diagnosticimplications. Clin Chem. 2011;57:1650-69.

44. Theurl M, Theurl I, Hochegger K, et al. Kupffer cells modulate iron homeostasis in mice via regulation of hepcidin expression. J Mol Med. 2008;86:825-35.

45. Montosi G, Corradini E, Garuti C, et al. Kupffer cells and macrophages are not required for hepatic hepcidin activation during iron overload. Hepatology. 2005;41:545-52.

46. Lou DQ, Lesbordes JC, Nicolas G, et al. Iron- and inflammation-induced hepcidin gene expression in mice is not mediated by Kupffer cells in vivo. Hepatology. 2005;41:1056-64.

47. Song SN, Iwahashi M, Tomosugi N, et al. Comparative evaluation of the effects of treatment with tocilizumab and TNF-alpha inhibitors on serum hepcidin, anemia response and disease activity in rheumatoid arthritis patients. Arthritis Res Ther. 2013;15:R141.

48. Castell JV, Gomez-Lechon MJ, David M, et al. Interleukin6 is the major regulator of acute phase protein synthesis in adult human hepatocytes. FEBS Lett. 1989;242:237-9.

49. Chen G, Fillebeen C, WangJ, Pantopoulos K. Overexpression of iron regulatory protein 1 suppresses growth of tumor xenografts. Carcinogenesis. 2007;28:785-91.

50. Smilevska T, Stamatopoulos K, Samara M, et al. Transferrin receptor-1 and 2 expression in chronic lymphocytic leukemia. Leuk Res. 2006;30:183-9.

51. Andrews SC, Robinson AK, Rodriguez-Quinones F. Bacterial iron homeostasis. FEMS Microbiol Rev. 2003;27:215-37.

52. Bachman MA, Lenio S, Schmidt L, Oyler JE, Weiser JN. Interaction of lipocalin 2, transferrin, and siderophores determines the replicative niche of Klebsiella pneumoniae during pneumonia. MBio. 2012;3:00224-00211.

53. Barber MF, Elde NC. Nutritional immunity. Escape from bacterial iron piracy through rapid evolution of transferrin. Science. 2014;346:1362-6.

54. Soares MP, Weiss G. The Iron age of host-microbe interactions. EMBO Rep. 2015;16:1482-500.

55. Ganz T, Nemeth E. Iron homeostasis in host defence and inflammation. Nat Rev Immunol. 2015;15:500-10.

56. Schaible UE, Kaufmann SH. Iron and microbial infection. Nat Rev Microbiol. 2004;2:946-53.

57. Skaar EP. The battle for iron between bacterial pathogens and their vertebrate hosts. PLoS Pathog. 2010;6:e1000949.

58. Schmidt PJ, Toran PT, Giannetti AM, Bjorkman PJ, Andrews NC. The transferrin receptor modulates Hfedependent regulation of hepcidin expression. Cell Metab. 2008;7:205-14.

59. Bartnikas TB, Andrews NC, Fleming MD. Transferrin is a major determinant of hepcidin expression in hypotransferrinemic mice. Blood. 2011;117:630-7. 
60. Tanno T, Bhanu NV, Oneal PA, et al. High levels of GDF15 in thalassemia suppress expression of the iron regulatory protein hepcidin. NatMed. 2007;13:1096-101.

61. Tanno T, Porayette P, Sripichai O, et al. Identification of TWSG1 as a second novel erythroid regulator of hepcidin expression in murine and human cells. Blood. 2009;114:181-6.

62. Frazer DM, Wilkins SJ, Darshan D, BadrickAC, McLaren GD, Anderson GJ. Stimulated erythropoiesis with secondary iron loading leads to a decrease in hepcidin despite an increase in bone morphogenetic protein 6 expression. Br J Haematol. 2012;157:615-26.

63. Kautz L, Jung G, Nemeth E, Ganz T. Erythroferrone contributes to recovery from anemia of inflammation. Blood. 2015;124:2569-74.

64. Theurl I, Finkenstedt A, Schroll A, et al. Growth differentiation factor 15 in anaemia of chronic disease, iron deficiency anaemia and mixed type anaemia. $\mathrm{Br} \mathrm{J}$ Haematol. 2010;148:449-55.

65. Sonnweber T, Nachbaur D, Schroll A, et al. Hypoxia induced downregulation of hepcidin is mediated by platelet derived growth factor BB. Gut. 2014;63:1951-9.

66. Andriopoulos B Jr., Corradini E, Xia Y, et al. BMP6 is a key endogenous regulator of hepcidin expression and iron metabolism. NatGenet. 2009;41:482-7.

67. Babitt JL, Huang FW, Wrighting DM, et al. Bone morphogenetic protein signaling by hemojuvelin regulates hepcidin expression. Nat Genet. 2006;38:531-9.

68. Enns CA, Ahmed R, Wang J, et al. Increased iron loading induces Bmp6 expression in the non-parenchymal cells of the liver independent of the BMP-signaling pathway. PLoS ONE. 2013;8:e60534.

69. Armitage AE, Eddowes LA, Gileadi U, et al. Hepcidin regulation by innateimmune and infectious stimuli. Blood. 2011;118:4129-39.

70. Nemeth E, Rivera S, Gabayan V, et al. IL-6 mediates hypoferremia of inflammation by inducing the synthesis of the iron regulatory hormone hepcidin. J Clin Invest. 2004;113:1271-6.

71. Schaefer B, Haschka D, Finkenstedt A, et al. Impaired hepcidin expression in alpha-1-antitrypsin deficiency associated with iron overload and progressive liver disease. Hum MolGenet. 2015;24:6254-63.

72. CanaliS, Core AB, Zumbrennen-Bullough KB, etal. Activin B induces noncanonical SMAD1/5/8 signaling via BMP type I receptors in hepatocytes: evidence for a role in hepcidin induction by inflammation in male mice. Endocrinology. 2016;: doi:10.1210/en.2015-1747.

73. Yang Q, Jian J, Katz S, Abramson SB, Huang X. 17betaEstradiol inhibits iron hormone hepcidin through an estrogen responsive element half-site. Endocrinology. 2012;153:3170-8.

74. Higham JM, O'Brien PM, Shaw RW. Assessment of menstrual blood loss using a pictorial chart. Br J Obstet Gynaecol. 1990;97:734-9.

75. Li X, Rhee DK, Malhotra R, et al. Progesterone receptor membrane component- 1 regulates hepcidin biosynthesis. JClin Invest. 2016;126:389-401.

76. Laine F, Angeli A, Ropert M, et al. Variations of hepcidin and iron-status parameters during the menstrual cycle in healthy women. Br J Haematol. 2015; doi:10.1111/bjh.13906.

77. Przybylowski P, Malyszko JS, Macdougall IC, Malyszko J. Iron metabolism, hepcidin, and anemia in orthotopic heart transplantation recipients treated with mammalian target of rapamycin. Transplant Proc. 2013;45:387-90.
78. Kim A, Fung E, Parikh SG, et al. A mouse model of anemia of inflammation: complex pathogenesis with partial dependence on hepcidin. Blood. 2014;123:1129-36.

79. Gardenghi S, Renaud TM, Meloni A, et al. Distinct roles for hepcidin and interleukin-6 in the recovery from anemia in mice injected with heat-killed Brucella abortus. Blood. 2014;123:1137-45.

80. Lutz HU, Bussolino F, Flepp R, et al. Naturally occurring anti-band- 3 antibodies and complement together mediate phagocytosis of oxidatively stressed human erythrocytes. Proc Natl Acad Sci USA. 1987;84:7368-72.

81. Powell RJ, Machiedo GW, Rush BF Jr., Dikdan G. Oxygen free radicals: effect on red cell deformability in sepsis. Crit Care Med. 1991;19:732-5.

82. Jelkmann W. Proinflammatory cytokines lowering erythropoietin production. J Interferon Cytokine Res. 1998;18:555-9.

83. Rodriguez RM, Corwin HL, Gettinger A, Corwin MJ, Gubler D, Pearl RG. Nutritional deficiencies and blunted erythropoietin response as causes of the anemia of critical illness. JCrit Care. 2001;16:36-41.

84. Artunc F, Risler T. Serum erythropoietin concentrations and responses to anaemia in patients with or without chronic kidney disease. Nephrol Dial Transplant. 2007;22:2900-8.

85. Icardi A, Paoletti E, De Nicola L, Mazzaferro S, Russo R, Cozzolino M. Renal anaemia and EPO hyporesponsiveness associated with vitamin D deficiency: the potential role of inflammation. Nephrol Dial Transplant. 2013;28:1672-9.

86. Bacchetta J, Zaritsky JJ, Sea JL, et al. Suppression of iron-regulatory hepcidin by vitamin D. J Am Soc Nephrol. 2014;25:564-72.

87. Fehr T, Ammann P, Garzoni D, et al. Interpretation of erythropoietin levels in patients with various degrees of renal insufficiency and anemia. Kidney Int. 2004;66:1206-11.

88. Forni GL, Girelli D, Lamagna M, et al. Acquired iron overload associated with antitransferrin monoclonal immunoglobulin: a case report. Am J Hematol. 2008;83:932-4.

89. Forni GL, Pinto V, Musso M, et al. Transferrin-immune complex disease: a potentially overlooked gammopathy mediated by IgM and IgG. Am J Hematol. 2013;88:1045-9.

90. Taniguchi S, Dai CH, Price JO, Krantz SB. Interferon gamma downregulates stem cell factor and erythropoietin receptors but not insulin-like growth factor-I receptors in human erythroid colony-forming cells. Blood. 1997;90:2244-52.

91. Wang CQ, Udupa KB, Lipschitz DA. Interferon-gamma exerts its negative regulatory effect primarily on the earliest stages of murine erythroid progenitor cell development. J Cell Physiol. 1995;162:134-8.

92. Maciejewski JP, Selleri C, Sato T, et al. Nitric oxide suppression ofhumanhematopoiesisinvitro. Contribution to inhibitory action of interferon-gamma and tumor necrosis factor-alpha. J Clin Invest. 1995;96:1085-92.

93. Libregts SF, Gutierrez L, Bruin AM de, et al. Chronic IFNgamma production in mice induces anemia by reducing erythrocyte life span and inhibiting erythropoiesis through an IRF-1/PU.1 axis. Blood. 2011;118:2578-88.

94. Lai CM, Swaminathan N, Beilharz MW, Papadimitriou J, Klinken SP. Interferon-alpha inhibits erythropoietininduced proliferation, but not differentiation, and restricts erythroleukemia development. J Interferon Cytokine Res. 1995;15:669-75.

95. Gunnell J, Yeun JY, Depner TA, Kaysen GA. Acute-phase response predicts erythropoietin resistance in hemodialysis and peritoneal dialysis patients. Am J Kidney Dis. 1999;33:63-72. 
96. Gilani ST, Khan DA, Khan FA, Ahmed M. Adverse effects of low dose methotrexate in rheumatoid arthritis patients. JColl Physicians Surg Pak. 2012;22:101-4.

97. Kozak N, Friedman J, Schattner A. Etanercept-associated transient bone marrow aplasia: a review of the literature and pathogenetic mechanisms. Drugs R D. 2014;14:155-8.

98. Skaar EP, Humayun M, Bae T, DeBord KL, Schneewind O. Iron-source preference of Staphylococcus aureus infections. Science. 2004;305:1626-8.

99. Sartorello R, Budu A, Bagnaresi P, et al. In vivo uptake of a haem analogue $\mathrm{Zn}$ protoporphyrin IX by the human malaria parasite P. falciparum-infected red blood cells. Cell Biol Int. 2010;34:859-65.

100. Prentice AM, Doherty CP, Abrams SA, et al. Hepcidin is the major predictor of erythrocyte iron incorporation in anemic African children. Blood. 2012;119:1922-8.

101. Portugal S, Carret C, Recker M, et al. Host-mediated regulation of superinfection in malaria. Nat Med. 2011;17:732-7.

102. Minchella PA, Armitage AE, Darboe B, et al. Elevated Hepcidin is part of a complex relation that links mortality with iron homeostasis and anemia in men and women with HIV infection. J Nutr. 2015;145:1194-201.

103. Roelcke D. Cold agglutination. Transfus Med Rev. 1989;3:140-66.

104. Moldawer LL, Marano MA, Wei H, et al. Cachectin/tumor necrosis factor-alpha alters red blood cell kinetics and induces anemia in vivo. FASEB J. 1989;3:1637-43.

105. Ceresa IF, Noris P, Ambaglio C, Pecci A, Balduini CL. Thrombopoietin is not uniquely responsible for thrombocytosis in inflammatory disorders. Platelets. 2007;18:579-82.

106. Kulnigg-Dabsch S, Evstatiev R, Dejaco C, Gasche C. Effect of iron therapy on platelet counts in patients with inflammatory bowel disease-associated anemia. PLoS ONE. 2012; doi:10.1371/journal.pone.0034520.

107. Kaser A, Brandacher G, Steurer W, et al. Interleukin-6 stimulates thrombopoiesis through thrombopoietin: role in inflammatory thrombocytosis. Blood. 2001;98:2720-5.

108. Akan H, Guven N, Aydogdu I, Arat M, Beksac M, Dalva K. Thrombopoietic cytokines in patients with iron deficiency anemia with or without thrombocytosis. Acta Haematol. 2000;103:152-6.

109. Cohen LA, Gutierrez L, Weiss A, et al. Serum ferritin is derived primarily from macrophages through a nonclassical secretory pathway. Blood. 2010;116:1574-84.

110. Fautrel B. Ferritin levels in adult Still's disease: any sugar? Joint Bone Spine. 2002;69:355-7.

111. Coffernils M, Soupart A, Pradier O, Feremans W, Neve P, Decaux G. Hyperferritinemia in adult onset Still's disease and the hemophagocytic syndrome. J Rheumatol. 1992;19:1425-7.

112. Theurl I, Aigner E, Theurl M, et al. Regulation of iron homeostasis in anemia of chronic disease and iron deficiency anemia: diagnostic and therapeutic implications. Blood. 2009;113:5277-86.

113. Zimmermann MB, Hurrell RF. Nutritional iron deficiency. Lancet. 2007;370:511-20.

114. Rimon E, Levy S, Sapir A, et al. Diagnosis of iron deficiency anemia in the elderly by transferrin receptor-ferritin index. Arch Intern Med. 2002;162:445-9.

115. Punnonen K, Irjala K, Rajamaki A. Serum transferrin receptor and its ratio to serum ferritin in the diagnosis of iron deficiency. Blood. 1997;89:1052-7.

116. Skikne BS, Punnonen K, Caldron $\mathrm{PH}$, et al. Improved differential diagnosis of anemia of chronic disease and iron deficiency anemia: a prospective multicenter evaluation of soluble transferrin receptor and the sTfR/log ferritin index. AmJ Hematol. 2011;86:923-7.
117. Archer NM, Brugnara C. Diagnosis of iron-deficient states. CritRev Clin Lab Sci. 2015;52:256-72.

118. Bergamaschi G, Di Sabatino A, Albertini R, et al. Serum hepcidin in inflammatory bowel diseases: biological and clinical significance. Inflamm Bowel Dis. 2013;19:2166-72.

119. Theurl M, Nairz M, Schroll A, et al. Hepcidin as a predictive factor and therapeutic target in erythropoiesis-stimulating agent treatment for anemia of chronic disease in rats. Haematologica. 2014;99:1516-24.

120. Bregman DB, Morris D, Koch TA, He A, Goodnough LT. Hepcidin levels predict nonresponsiveness to oral iron therapy in patients with iron deficiency anemia. Am J Hematol. 2013;88:97-101.

121. Tessitore N, Girelli D, Campostrini N, et al. Hepcidin is not useful as a biomarker for iron needs in haemodialysis patients on maintenance erythropoiesis-stimulating agents. NephrolDial Transplant. 2010;25:3996-4002.

122. Valenti L, Messa P, Pelusi S, Campostrini N, Girelli D. Hepcidin levels in chronic hemodialysis patients: a critical evaluation. Clin Chem Lab Med. 2014;52:613-9.

123. Kroot JJ, Herwaarden AE van, Tjalsma H, Jansen RT, Hendriks JC, Swinkels DW. Second round robin for plasma hepcidin methods: first steps toward harmonization. Am J Hematol. 2012;87:977-83.

124. Schaible UE, Kaufmann SH. A nutritive view on the hostpathogen interplay. Trends Microbiol. 2005;13:373-80.

125. Nairz M, Haschka D, Demetz E, Weiss G. Iron at theinterface of immunity and infection. Front Pharmacol. 2015;5:152.

126. Nairz M, Schroll A, Moschen AR, et al. Erythropoietin contrastingly affects bacterial infection and experimental colitis by inhibiting nuclear factor-kappaB-inducible immune pathways. Immunity. 2011;34:61-74.

127. Nairz M, Sonnweber T, Schroll A, Theurl I, Weiss G. The pleiotropic effects of erythropoietin in infection and inflammation. Microbes Infect. 2012;14:238-46.

128. Yasuda Y, Fujita Y, Matsuo T, et al. Erythropoietin regulates tumour growth of human malignancies. Carcinogenesis. 2003;24:1021-9.

129. Vamvakas EC, Blajchman MA. Deleterious clinical effects of transfusion-associated immunomodulation: fact or fiction? Blood. 2001;97:1180-95.

130. Drueke TB, Parfrey PS. Summary of the KDIGO guideline on anemia and comment: reading between the (guide)line(s). Kidney Int. 2012;82:952-60.

131. Weiss G, Schett G. Anaemia in inflammatory rheumatic diseases. Nat Rev Rheumatol. 2013;9:205-15.

132. Shayeghi M, Latunde-Dada GO, Oakhill JS, et al. Identification of an intestinal heme transporter. Cell. 2005;122:789-801.

133. Qiu A, Jansen M, Sakaris A, et al. Identification of an intestinal folate transporter and the molecular basis for hereditary folate malabsorption. Cell. 2006;127:917-28.

134. Moretti D, Goede JS, Zeder C, et al. Oral iron supplements increase hepcidin and decrease iron absorption from daily or twice-daily doses in iron-depleted young women. Blood. 2015;126:1981-9.

135. Nielsen OH, Ainsworth M, Coskun M, Weiss G. Management of iron-deficiency anemia in inflammatory bowel disease: a systematic review. Medicine (Baltimore). 2015;94:e963.

136. Cepeda-Lopez AC, Melse-Boonstra A, Zimmermann MB, Herter-Aeberli I. In overweight and obese women, dietary iron absorption is reduced and the enhancement of iron absorption by ascorbic acid is one-half that in normalweight women. Am J Clin Nutr. 2015;102:1389-97.

137. Geisser P, Burckhardt S. The pharmacokinetics and pharmacodynamics of iron preparations. Pharmaceutics. 2011;3:12-33. 
138. Rampton D, Folkersen J, Fishbane S, et al. Hypersensitivity reactions to intravenous iron: guidance for risk minimization and management. Haematologica. 2014;99:1671-6.

139. Hardy S, Vandemergel X. Intravenous iron administration and hypophosphatemia in clinical practice. Int J Rheumatol. 2015; doi:10.1155/2015/468675.

140. Chaston T, Chung B, Mascarenhas M, et al. Evidence for differential effects of hepcidin in macrophages and intestinal epithelial cells. Gut. 2008;57:374-82.

141. Kitsati N, Liakos D, Ermeidi E, et al. Rapid elevation of transferrin saturation and serum hepcidin concentration in hemodialysis patients after intravenous iron infusion. Haematologica. 2015;100:e80-e83.

142. Fernandez-Rodriguez AM, Guindeo-Casasus MC, MoleroLabarta T, et al. Diagnosis of iron deficiency in chronic renal failure. Am J Kidney Dis. 1999;34:508-13.

143. Bennett CL, Jacob S, Hymes J, Usvyat LA, Maddux FW. Anaphylaxis and hypotension after administration of peginesatide. NEnglJ Med. 2014;370:2055-6.

144. Pincus T, Olsen NJ, Russell IJ, et al. Multicenter study of recombinant human erythropoietin in correction of anemia in rheumatoid arthritis. Am J Med. 1990;89:161-8.

145. Henry DH, Beall GN, Benson CA, etal. Recombinanthuman erythropoietin in the treatment of anemia associated with human immunodeficiency virus (HIV) infection and zidovudine therapy. Overview of four clinical trials. Ann Intern Med. 1992;117:739-48.

146. Uhlig K, Berns JS, Kestenbaum B, et al. KDOQI US commentary on the2009 KDIGOClinical Practice Guideline for the Diagnosis, Evaluation, and Treatment of CKDMineral and Bone Disorder (CKD-MBD). Am J Kidney Dis. 2010;55:773-99.

147. Santini V. Anemia as the main manifestation of myelodysplastic syndromes. Semin Hematol. 2015;52:348-56.

148. Bennett CL, Spiegel DM, Macdougall IC, et al. A review of safety, efficacy, and utilization of erythropoietin, darbepoetin, and peginesatide for patients with cancer or chronickidney disease: a reportfrom the Southern Network on Adverse Reactions (SONAR). Semin Thromb Hemost. 2012;38:783-96.

149. Dignass AU, Gasche C, Bettenworth D, et al. European consensus on the diagnosis and management of iron deficiency and anaemia in inflammatory bowel diseases. JCrohns Colitis. 2015;9:211-22.

150. Poli M, Asperti M, Ruzzenenti P, Regoni M, Arosio P. Hepcidin antagonists for potential treatments of disorders with hepcidin excess. Front Pharmacol. 2014;5:86.
151. Ganz T, Nemeth E. The hepcidin-ferroportin system as a therapeutic target in anemias and iron overload disorders. Hematology Am Soc Hematol Educ Program. 2011;2011(1):538-42.

152. Theurl I, Schroll A, Sonnweber T, et al. Pharmacologic inhibition of hepcidin expression reverses anemia of chronic inflammation in rats. Blood. 2011;118:4977-84.

153. Cooke KS, Hinkle B, Salimi-Moosavi H, et al. A fully human anti-hepcidin antibodymodulates iron metabolismin both mice and nonhuman primates. Blood. 2013;122:3054-61.

154. Eijk LT van, John AS, Schwoebel F, et al. Effect of the antihepcidin Spiegelmer lexaptepid on inflammationinduced decrease in serum iron in humans. Blood. 2014;124:2643-6.

155. Fung E, Sugianto P, Hsu J, Damoiseaux R, Ganz T, Nemeth E. High-throughput screening of small molecules identifies hepcidin antagonists. Mol Pharmacol. 2013;83:681-90.

156. Skerra A. Alternative binding proteins: anticalins harnessing the structural plasticity of the lipocalin ligand pocket to engineer novel binding activities. FEBS J. 2008;275:2677-83.

157. Hohlbaum AM, Trentman S, Gille H. et al. Discovery and PreclinicalCharacterization of a NovelHepcidinAntagonist with TunablePK/PDProperties for the Treatment ofAnemia in Different Patient Populations. 53rd ASH Annual Meeting and Exposition, 2011.

158. Moebius U, Feurer W, Fenzl E, Swelm R van, Swinkels D, Hohlbaum A. A phase I study investigating the safety, tolerability, pharmakokinetics and pharmacodynamic activty of the hepcidin antagonist PRS-80\#022. Results from a randomzed, placebo controlled, double-blind study following single administration to healthy subjects. Blood. 2015;126:536-536.

159. Witcher DR, Leung D, Hill KA, et al. LY2928507, an antibody targeting ferroportin, is a potent inhibitor of hepcidin activity and increases iron mobilization in normal cynomolgus monkeys. Blood. 2013;122. https://ash. confex.com/ash/2013/webprogram/Paper58923.html

160. Soni H. Prolyl hydroxylase domain-2 (PHD2) inhibition may be a better therapeutic strategy in renal anemia. Med Hypotheses. 2014;82:547-50.

161. World Health Organization. Haemoglobin concentrations for the diagnosis of anaemia and assessment of severity. Vitamin and Mineral Nutrition Information System. Geneva 2011. http://www.who.int/vmnis/ indicators/haemoglobin/en/. WHO reference number: WHO/NMH/NHD/MNM/11.1. Accessed: 01/01/2016 